\title{
病院感染対策における薬刻師の活動と他職種からの評価
}

\section{継田 雅美}

\section{Pharmacist's Activity in Control and Evaluation by Other Healthcare Proffessionals}

\author{
Masami Tsugita
}

Pharmacy of Niitsu Medical Center Hospital

(2012 年 1 月 10 日 受付 $\cdot 2012$ 年 3 月 15 日 受理)

\begin{abstract}
要旨
新潟県内の感染認定薬剤師，ICD 医師，ICN に対して，薬剤師の感染対策に掞ける業務につい てのアンケート調査を行った. その結果, 感染対策に対する今後の薬剂師業務展開の方向は抗菌薬 の適正使用に重点を置き, 抗菌薬の選択と投与設計に積極的にかかわっていくことが重要と思われ た．また，消毒薬の適正使用にも積極的にかかわっていくことも必要であり，そのために感染の認 定薬戍師を増やすこと, さらに, 薬剤部全体の業務として注射薬の無菌調製の範囲を広げていくこ とも考えていく必要があると思われた。
\end{abstract}

Key words : 感染対策, 薬剤師, インフェクションコントロールチーム(ICT)

\section{はじめに}

現在, 多くの病院での感染対策は infection control team (以下，ICT)が中心となり，そのメンバーである 医師・看護師・臨床検査技師・薬剂師などがそれぞれ の役割を担っている．薬剤師は主に消毒薬と抗菌薬の 適正使用により，施設内の感染伝播の防止と耐性菌発生 の抑制などに寄与している。また, therapeutic drug monitoring (以下，TDM)の手法を用いた感染症治療へ の参画も行っている. 一方, 2005 年より日本病院薬剤 師会で感染制御専門薬剤師制度が立ち上がり，感染制御 専門薬剤師の認定が行われ，その後 2008 年には現場で 感染対策に関わっているが論文や学会発表が要件ではな い感染制御認定薬剤師が認定されている．また，日本化 学療法学会では 2009 年に治療に重点をおいた抗菌化学 療法認定薬剤師を認定し，薬剤師のなかでも感染に専門 的な知識を持つ薬剤師が次々誕生している，新潟県にお いても，2011年 10 月現在，認定を受けた薬剤師が 26 名(認定の重複あり)存在している.このたび, 病院内の 感染対策における薬剤師の役割に注目し，薬剤師がその 役割を果たしているのかを感染対策専門家の医師(infection control doctor，以下，ICD 医師）と専門看護師 (in- fection control nurse，以下 ICN)に評価してもらい，同 時に感染の認定を受けている薬剤師自らの評価を行うこ とで, 病院感染において薬剤師が役立っているのか，ま た，ぞのような活動をすべきなのかを明らかにするため アンケート調査を行ったので報告する.

\section{対象と方法}

対象は, 新潟県内の病院に勤務されている, ICD 医 師 78 名, ICN22 名, 日本病院薬剤師会に抢ける感染認 定を持つ薬剤師 23 名である. 同意書に記名されたもの を有効回答とした。

アンケート内容(表 1)は，医師・看護師に対しては， まず ICTへの薬剤師の関与の度合いと，その薬剤師が 感染症に関る認定資格を有しているかの調査を行った。 次に, 薬剤師が担っている業務と, 業務の代行を含めた 今後の要望を聞いた。薬剤師業務については，「薬剤師 のための感染制御マニュアル第 2 版」1) から抜粋改変し た上で列挙し，選択してもらった．その他，自由記載欄 を設けた，薬剤師に対しては，現在行っている業務と今 後取り組む必要があると感じている業務を，医師・看護 師へのアンケートと同じ業務内容を列挙し選択してもら った．医師・看護師への質問で，役立っていると思う業 務(問 4), もっとやってもらいたい業務(問 5), 代行し 
表 1 アンケート内容

1. ICTに薬剤師は在籍していますか?

2. 認定を持つ薬剤師はいますか?

3. 薬剤師が現在行っている業務についての以下の選択肢に ○をつけてください(複数回答可)

4. 薬剤師が役立っていると思う業務に 1～5 位の順位をつ けてください。

5. もっと薬剤師にやってもらいたい業務について1〜 5 位 の順位をつけてください

6. 薬剤師に代行してもらいたい業務に1〜5 位の順位をつ けてください

\begin{tabular}{|c|c|}
\hline & 業 務 内 容 \\
\hline \multirow{3}{*}{ 消毒薬 } & (1)いろいろな場面での消毒薬の選択の指導 \\
\hline & (2)消毒薬使用時の指導 (濃度 ·温度 ·接触時間など) \\
\hline & (3)消毒薬の使用統計を出す \\
\hline \multirow{6}{*}{ 抗菌薬 } & (4)抗 MRSA 薬の TDM \\
\hline & (5)アミノグリコシド系薬の TDM \\
\hline & (6)カルバペネム系薬の TDM \\
\hline & (7)個々の患者に応じた投与設計(TDM 薬剤以外) \\
\hline & $\begin{array}{l}\text { (8)個々の患者に応じた抗菌薬の選択 (de-escalation } \\
\text { を含む) }\end{array}$ \\
\hline & (9)抗菌薬の使用統計を出す \\
\hline \multirow{6}{*}{ その他 } & (10注射薬の無菌調製 \\
\hline & (11感染対策マニュアルの作成・改訂 \\
\hline & (12院内で感染対策の教育 (講習会など) \\
\hline & (13院内の巡回指導 (ICT ラウンドを含む) \\
\hline & (14)ワクチン業務 \\
\hline & (15)その他 (自由記載) \\
\hline
\end{tabular}

てもらいたい業務（問 6) は 1 位〜 5 位までの順位づけを お願いした。薬剤師に対しては，医師・看護師がどのよ うに考えているかを推測して 1 位〜 5 位の順位づけをし てもらった. 1 位を 5 点, 2 位を 4 点…5 位を 1 点, と 点数化し各業務内容の合計点を回答された人数で除し平 均点を算出した。それらを比較し，他職種から見た薬剤 師の感染対策に対する関与の度合いと薬剤師に対する意 識・要望を集計し, 薬剤師の考えている業務が合致して いるか，それぞれの回答を突き合わせ評価した。

\section{結果}

1. アンケート回収率

薬剂師 23 名中 22 施設 22 名 $(95.7 \%)$, 看護師 22 名 中 13 施設 13 名 $(59.1 \%)$, 医師 78 名中 21 施設 29 名 (37.2\%)であった.

\section{2. 認定薬剤師のICT への関与}

22 名中, 専任と兼務を合わせて 19 名 $(86.4 \%)$ が ICT に参加していた。

\section{ICD 医師・ICN のいる施設での認定薬剤師}

ICD 医師在籍 21 施設中「ICT に薬剂師不在」は 3 施 設であり，「薬剤師が所属しているかどうかわからない」 という回答は 29 名中 2 名であった. 認定薬剤師につい ては，9 施設に在籍との回答であった. ICN13 名が在籍 する ICT にはすべて薬剤師が在籍していたが，そのう ち認定薬剂師は 6 施設のみであった.

\section{4. 感染対策における薬剤師の業務 (図 1)}

認定薬剤師が行っている業務としては，抗菌薬の使用 統計, 感染対策マニュアルの作成・改訂, 消毒薬の選択 の指導, 院内での感染対策の教育が上位であった．その 他として, 消毒薬の管理, 抗菌薬届出制の管理, 抗菌薬 長期投与チェック，配合変化チェック，無菌ではない注
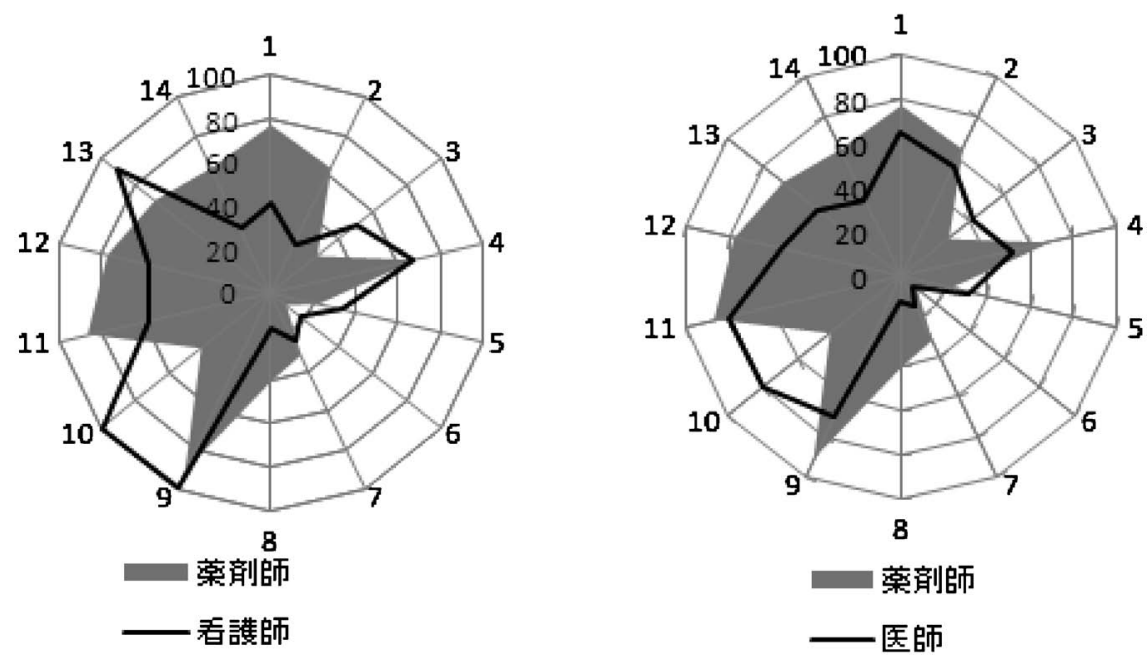

図 1 薬剤師が行っている感染対策に関する業務 
射薬調製が挙げられていた。 ICD 医師からみた薬剤師 業務では, マニュアルの作成・改訂, 注射薬の無菌調 製, 抗菌薬の使用統計, 消毒薬の指導がよく行われてお り, ICN からは, 注射薬の無菌調製, 抗菌薬の使用統 計, 院内の巡回指導がよく行われていると評価であった.

\section{5. 薬剤師の業務で役にたっていると} 思われる業務 (図 2)

認定薬剤師が役に立っていると感じている業務は, 抗 MRSA 薬のTDM, 消毒薬の指導, 注射薬の無菌調製 であった. ICD 医師からは注射薬の無菌調製, 抗菌薬 の使用統計, 消毒薬の指導, 抗 MRSA 薬の TDM が, ICN からは注射薬の無菌調製, 抗菌薬の使用統計, 抗 MRSA 薬の TDM との回答であった。 また, アンチバ イオグラムの作成を薬剤師が行っており, 役に立ってい るという意見があった。

\section{6. 現状よりもさらに進めていく 必要がある業務(図 3)}

認定薬剂師からは注射薬の無菌調製, 個々の患者に応 じた抗菌薬の投与設計，消毒薬の指導という意見が多か ったＩCD医師からは，個々の患者に応じた抗菌薬の 投与設計, 注射薬の無菌調製, 抗菌薬の選択, 抗 MRSA 薬の TDM を, ICN からは，個々の患者に応じ た抗菌薬の選択, 注射薬の無菌調製, 抗菌薬の投与設計 が求められていた。 また, ICN からは, 抗菌薬・消毒 薬の使用法に積極的介入を求める意見があった.

\section{7. 代行を求められている業務（図 4)}

認定薬剤師が医師・看護師の役割の代行をするべきと 考えている業務は，注射薬の無菌調製，個々の患者に応 じた抗菌薬の投与設計，抗菌薬の選択であったＩCD 医師からは，個々の患者に応じた抗菌薬の投与設計，抗
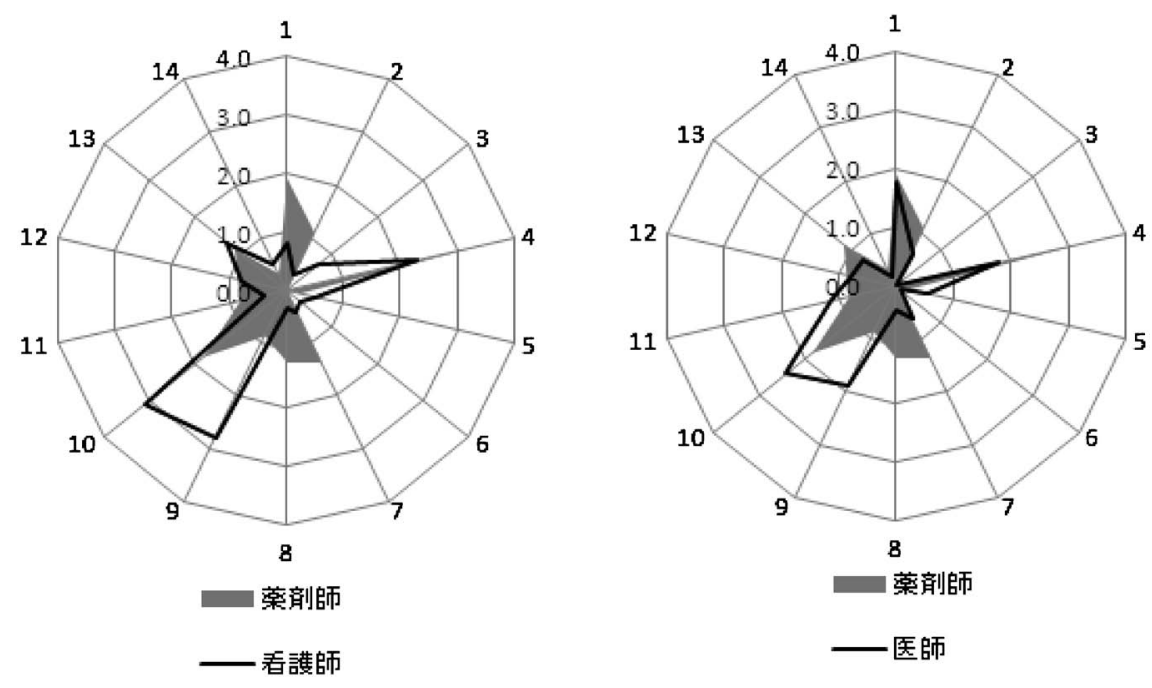

図 2 薬剤師が役に立っている感染対策に関する業務
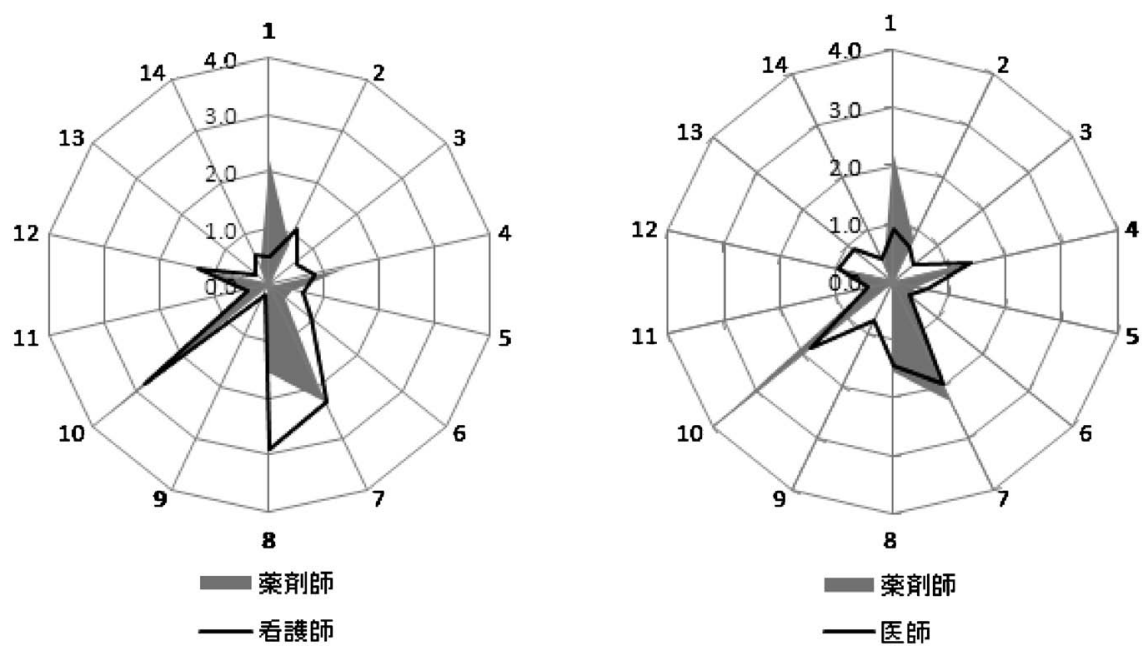

図 3 もっと薬剤師やってもらいたい感染対策に関する業務 

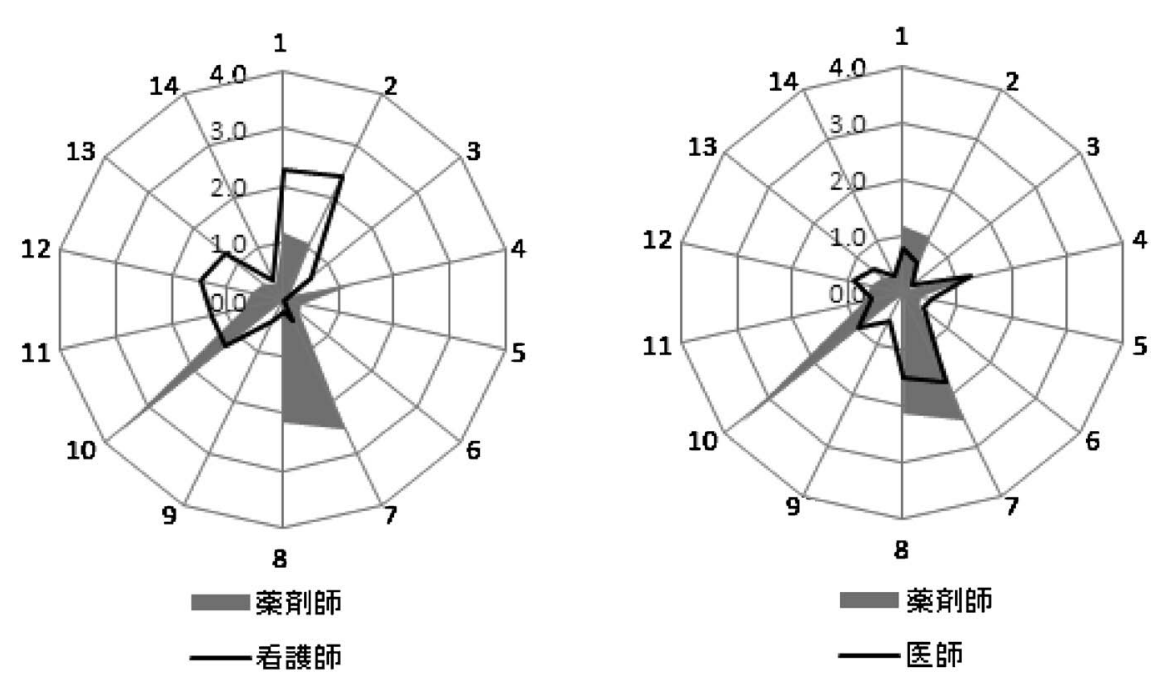

図 4 薬剤師に代行してもらいたい感染対策に関する業務

菌薬の選択，抗 MRSA 薬の TDM が挙げられていた が，業務の「代行」は難しいのではないかという意見 や，代行してもらいたい業務は無い(5 名)，TDM はす でに代行できている(1名)，という意見も見られた。 ICN からは, 消毒薬の選択, 使用時の指導についての 代行が求められていた。 また, 注射薬調製は本来薬剤師 の業務であり，看護師が代行している業務である，とい う意見があった。

\section{考察}

日本病院薬剤師会による専門薬剤師認定制度発足のお り，薬剤師の専門制度はどのような業務に必要かという アンケート調査では 1 位が感染対策であった ${ }^{2)}$. 専門薬 剂師認定後, 薬剂師自らの活動状況に関する調査は散見 されるが3 8), 他職種からの評価を調査した研究は久ら れない。このたびは新潟県内の ICD 医師と ICN から薬 剂師の感染対策への関わり方に対する評価を受け, かつ 認定薬剤師にも同様なアンケートをすることで ICT 内 での薬剤師の役割を改めて考える機会を得た.

まず認定薬剤師の業務であるが，19名が ICT に参加 していたが 3 名は参加していなかった．そのうち 2 施 設では同一施設内の他の認定薬剤師が ICT に参加して おり，1施設を除いて認定薬剤師のほとんどが院内の感 染対策業務に携わっていることがわかり, 新潟県の認定 薬剤師がその資格を十分に活かしていると思われた，業 務内容としては，「感染管理専門薬剂師の必要性に関す るアンケート調查集計結果報告」2)で ICT の薬剤師に求 められている業務として挙げられている抗菌薬チェッ ク・消毒薬チェック・マニュアル作成に対して, 抗 MRSA 薬の TDM · 抗菌薬の使用統計作成 · 消毒薬の 選択と使用時の指導 · マニュアルの作成と改訂の項目で
高い割合で行われていることがわかった．しかし，抗菌 薬の選択や投与設計へのかかわりの度合いはまだ低かっ た、また，業務のなかで注射薬の無菌調製の割合が 40.9\%であり，ICD 医師からの回答 $85.0 \%, I C N$ から の回答 $100 \%$ と大きく解離していることから，無菌調製 は薬剤部全体の業務であり, 認定薬剤師の業務ではない と考えて回答したものと思われる。また，ICTに薬剤 師が不在である施設が ICD 医師の回答より 2 施設あっ たこと, ICD 医師在籍 21 施設中 12 施設, ICN 在籍 13 施設中 7 施設での ICT に認定薬剤師が不在であったこ とから, 新潟県においてさらに認定薬剤師を増やし, 薬 剂師の ICTへの関与を深める必要性を感じた。

ICD 医師・ICN からみた薬剤師業務では，ICD 医師 は認定薬剤師とほぼ同じ回答であったが，ICN からは 消毒薬関連業務での評価が低かった. 認定薬剤師から は, 消毒薬に関する業務に対しても関与しているという 回答が多かったが，ICN が薬剤師より多くの消毒薬業 務を行っていることが考えられた.

ICD 医師・ICN から最も求められている業務として は，ともに抗菌薬の選択と投与設計，注射薬の無菌調製 が挙げられており, 特に抗菌薬の適正使用に対する薬剤 師の関与がまだ不足であることがうかがわれた．注射薬 の無菌調製に関しては, どの施設でも薬剂師の関与はあ るが，すべての注射薬調剤を行ってはいないためにこの ような結果となったと思われる.

代行業務については，ICD 医師に対して負担軽減に なるような医療行為ではない代行業務を意図した質問で あったが，代行は難しいという意見もあった。しかし， TDM を含む抗菌薬の適正使用を望む意見が多く, 認定 薬剤師の意見と一致していた。感染対策の専門家である ICD 医師が抗菌薬の選択 ·投与設計を薬剂師にも考え 
てほしいという意見であり，ICD 医師のいない施設も 多いことから, 今後薬剤師は積極的にかかわっていかな ければならないであろう。このことは医師の負担軽減に もつながると考える. ICN からは消毒薬の選択と使用 時の指導を代行してほしいという意見が多く, 現在 ICN がこの業務を行っており, 認定薬剂師だけでな く,すべての薬剤師が積極的にかかわっていかなければ ならない業務と思われた。

以上のように，感染対策に対する今後の薬剤師業務展 開の方向は抗菌薬の適正使用に重点を置き, 抗菌薬の選 択と投与設計に積極的にかかわっていくことが重要と思 われる. また，消毒薬の適正使用にも積極的にかかわっ ていくことも必要であり, そのために感染の認定薬剤師 を増やすこと, さらに, 薬剤部全体の業務として注射薬 の無菌調製の範囲を広げていくことも考えていく必要が あると思われる。

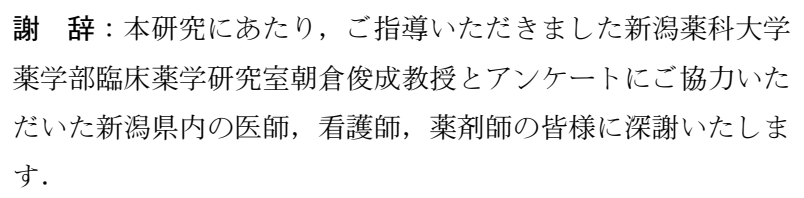

利益相反について : 利益相反はない.
文献

1）社日本病院薬剤師会監修: 薬剤師のための感染制御マ二 ュアル第 2 版. 日本病院薬剂師会感染制御専門薬剂師 部門研修委員会編集, 薬事日報社, 東京, 2008. p. 345.

2）全田 浩, 仲川義人, 白石 正, 太田 伸, 尾家重治, 古川裕之，他：感染管理専門薬剤師の必要性に関するア ンケート調査集計結果報告. 日病薬師会誌 2004 ; $40(2): 195-8$

3）前間邦生, 橋本和樹, 井上雅子, 藤井重貞, 国武有光, 原田秀徳，他：専門薬剂師としての活動状況に関する実 態調査. 九州薬学会会報 2006; 60(9): 85-90.

4）樋口多恵子, 長井一彦, 阿部政典, 大久保耕司, 継田雅 美 : 抗菌薬適正使用と薬剤師のかかわり一新潟県の現 状一. 日病薬師会誌 2008; 44(10): 1501-3.

5）伊東弘樹, 佐藤雄己, 小坂隆介, 後藤俊元, 阿部浩子, 武山正治：地域県病院薬剤師会における感染制御専門薬 剂師への意識調査と感染対策の取り組みの現状。日病薬 師会誌 2007; 43(11): 1549-53.

6) 早坂正孝, 千葉博暁, 渡部美帆, 小松 真, 高橋敏紀 : KKR 病院にお打病院感染制御に関する実態調査一感 染対策に関する薬剂部の取り組みと今後の課題一。共済 医報 2007; 56(3): 213-6.

7）千葉博暁, 高橋敏紀, 渡部美帆, 小松 真, 早坂正孝 : 宮城県に抢ける病院感染制御に関する実態調査一感染防 止策に対する薬剤部の取り組みと今後の課題一. 医薬品 相互作用研究 2007; 30(2): 69-75.

8）高橋嘉寛, 汐月良江, 入江英治, 門脇大介, 花田さゆ り，藤井憲一郎，他：熊本県における感染対策に対する 薬剂師の関与 · 意識に関する調査. 日病薬師会誌 2005 ; $41(7): 883-5$

〔連絡先：干956-0025 新潟市秋葉区古田 610 番地 新津医療センター病院薬剤局 継田雅美 E-mail: tsugita@niitsu-kenshinkai.com]

\title{
Pharmacist's Activity in Control and Evaluation by Other Healthcare Proffessionals
}

\author{
Masami Tsugita
}

Pharmacy of Niitsu Medical Center Hospital

\begin{abstract}
A questionnaire about the activities of pharmacists against infection was sent to infection authorization pharmacists, infection control physicians, and infection control nurses in Niigata Prefecture. The results indicate that it is important for future pharmacist business development against infection to actively investigate selection of antimicrobial agents and medication design with emphasis on correct use of antimicrobial agents, and correct use of antiseptics. Therefore, the infection authorization of pharmacists should be increased, and the range of sterile manufacture of injections extended further in the medication manufacturing business.
\end{abstract}

Key words : infection control, pharmacist, infection control team(ICT) 